\title{
Effects of time and temperature on blood gas and electrolytes in equine venous blood
}

\author{
José Dantas Ribeiro Filho ${ }^{1}$, Paulo Vinícius de Morais Santos ${ }^{1}$, Samuel Rodrigues Alves ${ }^{1}$, \\ Lorena Chaves Monteiro ${ }^{1}$, Caio Monteiro Costa ${ }^{1}$, Rinaldo Batista Viana ${ }^{2}$, \\ Marcel Ferreira Bastos Avanza ${ }^{1}$, Waleska de Melo Ferreira Dantas ${ }^{3}$, \\ Micheline Ozana da Silva ${ }^{1}$ \\ ${ }^{1}$ Universidade Federal de Viçosa (UFV), Department of Veterinary, Viçosa, MG, Brazil \\ ${ }^{2}$ Universidade Federal Rural da Amazônia (UFRA), Belém, PA, Brazil \\ ${ }^{3}$ Centro Universitário de Viçosa (Univiçosa), Viçosa, MG, Brazil
}

Received December 2, 2019

Accepted September 14, 2020

\begin{abstract}
This study aimed to evaluate the viability time of horse venous blood samples kept at laboratory temperature (LT) and in water with ice (WI), to perform blood gas analysis. Eleven blood samples were collected in duplicates from 10 healthy horses. The samples were transported to the laboratory and subjected to one of the $24 \mathrm{~h}$ storage method. Each pair of syringes was distinctly kept at LT or submerged in WI. Blood gas tests were performed at times T0h, T1h, T2h, T3h, T4h, T5h, T6h, T8h, T10h, T12h and T24h after collection. Analyses of electrolytes were also performed from the same samples. A difference in blood $\mathrm{pH}$ was found between the treatments $(P<0.05)$. From T4h, $\mathrm{pH}$ decreased in samples kept at LT, but in WI, $\mathrm{pH}$ did not change. For partial pressure of carbon dioxide $\left(\mathrm{pCO}_{2}\right)$, a difference between treatments $(P<0.05)$ was noted starting at T8h. In samples kept at LT, pCO increased; no changes occurred in samples stored in WI. There was a decrease in the base concentration beginning at $\mathrm{T} 5 \mathrm{~h}$ in samples kept at LT $(P<0.05)$, but no variation in samples kept in WI. These changes can be attributed to the erythrocyte metabolism, still active in vitro, which generates lactic acid from anaerobic glycolysis. The potassium concentration increased in samples kept in WI from T4h, with a gradual increase until T24h. Conservation of equine venous blood samples in WI is efficient in reducing cellular metabolism, thereby increasing the viability of samples for examination and interpretation of results.
\end{abstract}

Horse, acid-base, conservation, metabolism, samples

Blood gas analysis and electrolyte measurement are important laboratory tests for the characterization and assessment of the intensity of hydroelectrolytic and acid-base imbalances (Gokce et al. 2004; Ribeiro Filho et al. 2007). The blood gas analysis allows measuring the partial pressure of oxygen and carbon dioxide, as well as $\mathrm{pH}$ and other parameters necessary for interpretation of the acid-base balance, such as bicarbonate and base concentrations (Lisbôa et al. 2001; Ribeiro Filho et al. 2008).

Blood gas analysis can be performed to evaluate the patient's acid-base balance and gas exchange. If the objective is to assess the acid-base balance, a sample of the patient's venous blood should be collected. Venous blood carries cellular metabolism products allowing a more accurate assessment of the body's acid-base status. If the objective is to assess gas exchange, a patient's arterial blood sample should be obtained. Arterial blood comes directly from the lungs before being exposed to the metabolites of various body tissues and may demonstrate the effectiveness of gas exchange in the pulmonary alveoli (Bateman 2008).

In horses, hydroelectrolytic and acid-base alterations usually appear associated with important diseases or syndromes such as diarrhoea, colic, peritonitis, endotoxic shock,

Address for correspondence:

Micheline Ozana da Silva

Department of Veterinary

Universidade Federal de Viçosa (UFV)

Viçosa Campus, Ave Peter Henry Rolfs, s/n

36570-000, Viçosa, Minas Gerais, Brazil

Phone: +55 31998470095

E-mail: michelineozana@gmail.com

http://actavet.vfu.cz/ 
duodenitis-proximal jejunitis, renal failure, strenuous exercise, among others (Ribeiro Filho et al. 2007).

Even though acid-base abnormalities usually do not provide a diagnosis, restoration of normal blood $\mathrm{pH}$ should be considered in the treatment of any disease (Robinson 2004). The treatment of hydroelectrolytic and acid-base disorders is described in the literature, including expert opinion and recommendations. Blood gas analysis can guide the veterinarian to institute appropriate therapeutic interventions (Ribeiro Filho et al. 2008).

Despite the benefits of using haemogasometry in veterinary practice, there are certain limitations to its routine use. The cost of the equipment is relatively high, and it requires frequent maintenance to provide reliable results (Looney et al. 1998; Klein et al. 1999), which makes a portable blood gas meter less available for professionals working outside a hospital, making them dependent on qualified laboratories to do the testing.

The storage of samples during transport is critical to minimize the changes in blood that might affect the interpretation of results. Studies evaluating the effects of different syringe materials for collection, the time elapsed between collection and analysis, and the storage temperature of the sample for blood gas analysis have reported contradictory results. The objective of the present study was to evaluate the viability of venous blood samples from healthy horses, kept at laboratory temperature (LT) and in a water bath with ice (WI), to perform haemogasometry.

\section{Materials and Methods}

Ten clinically healthy horses of both sexes of the Mangalarga Marchador breed, aged between 5 and 13 years old, were used for the study. Blood samples were collected at the same times, in duplicate, for each evaluation time, from each animal, by puncture of the external jugular vein, using $25 \times 8 \mathrm{~mm}$ disposable needles (Jiangsu Jichun Medical Devices Co., Ltd., Jiangsu Province, China) coupled to $2 \mathrm{ml}$ plastic syringes containing lithium heparin (Greiner Bio-One GmbH, Kremsmünster, Oberösterreich, Austria). Routine care was taken during and after collection to avoid contact of blood with ambient gases: slow suction of the material, elimination of any gas bubbles present in the material, and closing the syringe with a plastic cap before homogenization.

After collection, the samples were immediately transferred to the laboratory, and each pair was subjected to one of the two methods of storage for $24 \mathrm{~h}$. Two groups were created: one group included non-preserved samples kept at LT between 22 and $28{ }^{\circ} \mathrm{C}$. Another group consisted of samples in WI. The syringes were submerged in WI at a temperature between 0 and $4{ }^{\circ} \mathrm{C}$; they were packed in a 7-1 expanded polystyrene thermal box (Knauf Isopor ${ }^{\circledR}$, São Paulo, São Paulo, Brazil), holding 21 of water and $2 \mathrm{~kg}$ of recyclable ice (cellulose gel, Group Polar, São Bernardo do Campo, São Paulo, Brazil) in flexible plastic packaging as used by Lisbôa et al. (2001).

Blood gas tests were performed within a maximum of $10 \mathrm{~min}$ in all samples at the following times: T0h (immediately after collection), T1h, T2h, T3h, T4h, T5h, T6h, T8h, T10h, T12h and T24h after collection, using the automatic $\mathrm{pH}$ and blood gas analyzer (ABL80 FLEX, Radiometer, Copenhagen, Denmark).

The variables measured were venous blood $\mathrm{pH}(\mathrm{pH})$, haemoglobin concentration $(\mathrm{cHb})$, partial oxygen pressure $\left(\mathrm{pO}_{2}\right)$, partial pressure of carbon dioxide $\left(\mathrm{pCO}_{2}\right)$, total oxygen concentration $\left(\mathrm{ctO}_{2}\right)$, total carbon dioxide concentration $\left(\mathrm{ctCO}_{2}\right)$, bicarbonate concentration $\left(\mathrm{cHCO}_{3}^{-}\right)$, base concentration (cBase), oxyhaemoglobin saturation $\left(\mathrm{sO}_{2}\right)$, sodium $\left(\mathrm{Na}^{+}\right)$, potassium $\left(\mathrm{K}^{+}\right)$, ionized calcium $\left(\mathrm{Ca}^{++}\right)$, chloride $\left(\mathrm{Cl}^{-}\right)$and anion gap $(\mathrm{AG})$.

The statistical program SAEG (SAEG-UFV 9.12007 ) was used for data analysis. The data were submitted to Lilliefors test, and to Cochran's and Bartlett's test to evaluate the normality of data and homogeneity of variance, respectively, as the premise of the analysis of variance (ANOVA), and the Tukey test was performed. All analyses were interpreted with the significance level of $5 \%(P<0.05)$.

\section{Results}

In blood $\mathrm{pH}$, a difference was found between the treatments. From $\mathrm{T} 4 \mathrm{~h}$, a decrease was detected in samples kept at LT, whereas in the WI treatment, the $\mathrm{pH}$ value remained unchanged throughout the experiment $(P>0.05)$. The $\mathrm{pO}_{2}$ showed no difference $(P>0.05)$ during the entire experiment for both treatments (Table 1$)^{2}$.

No difference $(P>0.05)$ was observed for the $\mathrm{sO}_{2}, \mathrm{ctO}_{2}$ and $\mathrm{ctCO}_{2}$ values between the treatments and over time. Haemoglobin concentration did not change. In $\mathrm{pCO}_{2}$, 

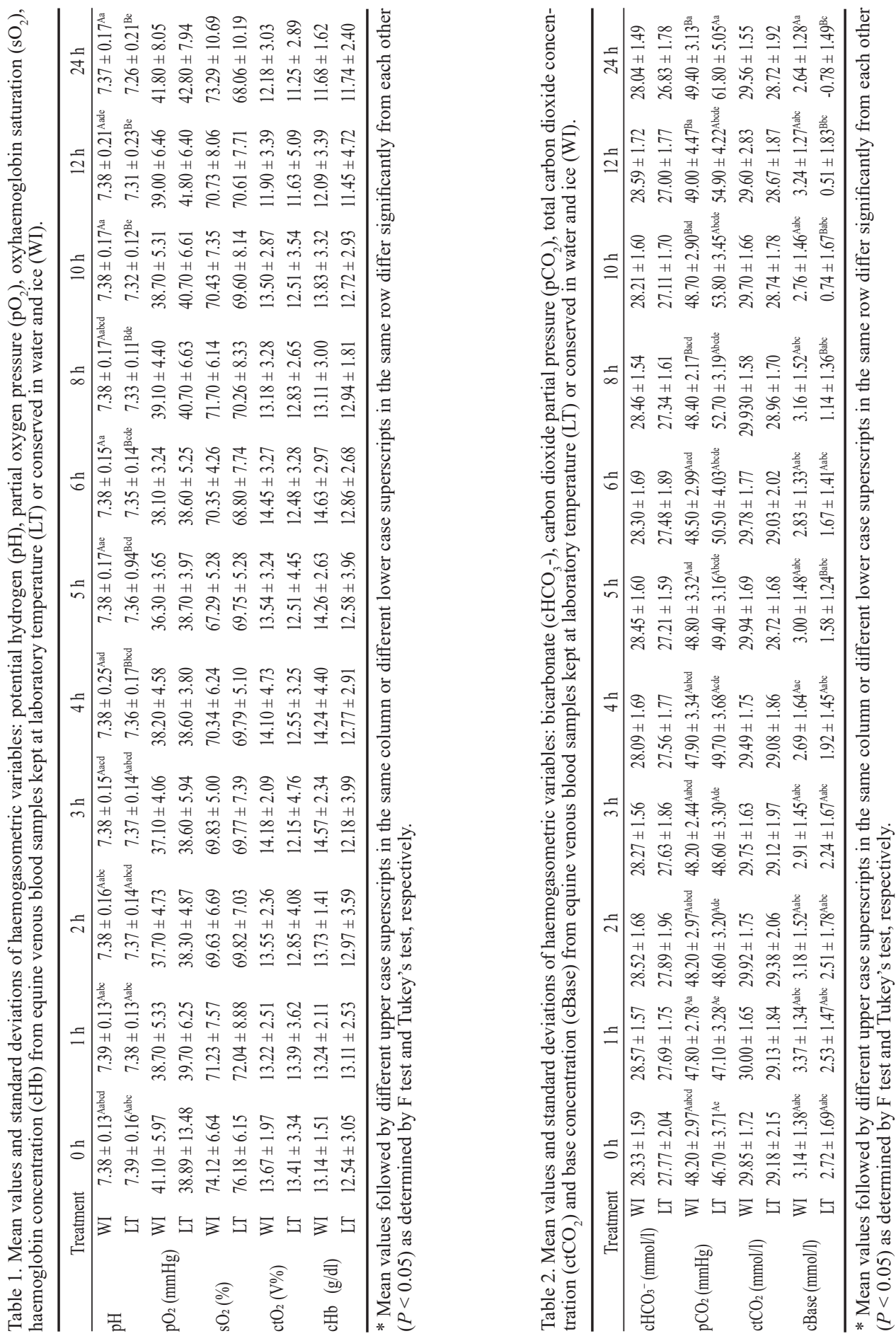


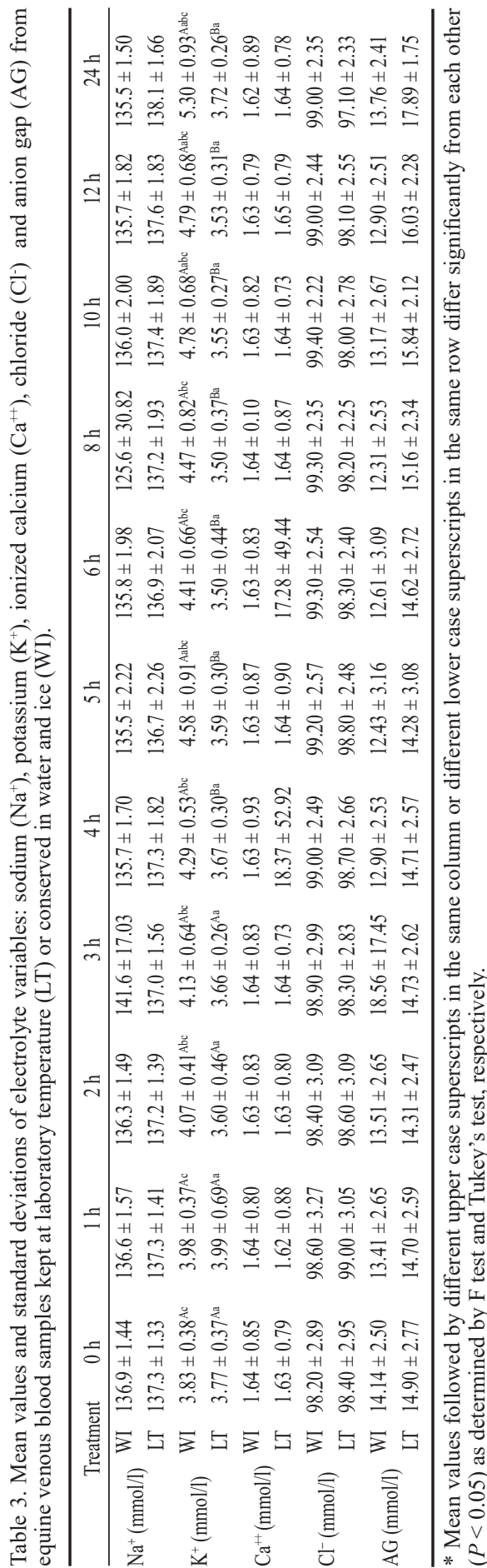

a difference $(P<0.05)$ was observed between the treatments after $8 \mathrm{~h}$ of storage (T8h). In samples kept at LT, the $\mathrm{pCO}_{2}$ values increased, whereas in samples kept in WI, $\mathrm{pCO}_{2}$ remained unchanged (Table 2 ).

The concentration of $\mathrm{CHCO}_{3}^{-}$remained stable in both treatments over time. A decrease in cBase from the $5^{\text {th }}$ hour was observed in samples kept at LT $(P<0.05)$, whereas in samples preserved in WI, no variation was observed (Table 2). There was a non-significant decrease in cBase over time in samples kept at LT.

The $\mathrm{Na}^{+}, \mathrm{Ca}^{++}$and $\mathrm{Cl}^{-}$concentrations remained stable for both $\mathrm{LT}$ and WI over time $(P>0.05$; Table 3$)$. As there were no significant variations in the $\mathrm{Na}^{+}, \mathrm{Cl}^{-}$and $\mathrm{HCO}_{3}^{-}$ concentrations, the anion gap did not differ $(P>0.05)$ between the treatments or within the treatments throughout the experiment. The $\mathrm{K}^{+}$concentration increased $(P<0.05)$ in the WI treatment samples after $3 \mathrm{~h}$ of storage, maintaining a gradual increase for up to $24 \mathrm{~h}$.

\section{Discussion}

Research has shown that most blood gases remain stable when kept in iced water. A decrease in blood $\mathrm{pH}$ in the samples kept at LT demonstrated that a low temperature slows down the metabolic processes that generate blood acidification. Kennedy et al. (2012) observed that the $\mathrm{pH}$ of equine blood remains stable when kept at $0{ }^{\circ} \mathrm{C}$ for at least $2 \mathrm{~h}$ after the collection.

Deane et al. (2004) found the same tendency as detected in the present study, when evaluating equine arterial blood stored in plastic syringes preserved in WI and at LT, emphasizing that the authors used arterial blood. A significant increase was observed in venous blood $\mathrm{pH}$ of samples kept at LT within the first hour after the collection. Unlike our study, Piccione et al. (2007) did not report changes in venous blood samples refrigerated at $4{ }^{\circ} \mathrm{C}$ for $24 \mathrm{~h}$. These authors found similar results in venous blood in sheep. Additionally, the same behaviour was observed in similar studies with venous blood from cattle (Lisbôa et al. 2001; Gokce et al. 2004), goats (Leal et al. 2010) and dogs (Rezende et al. 2007). 


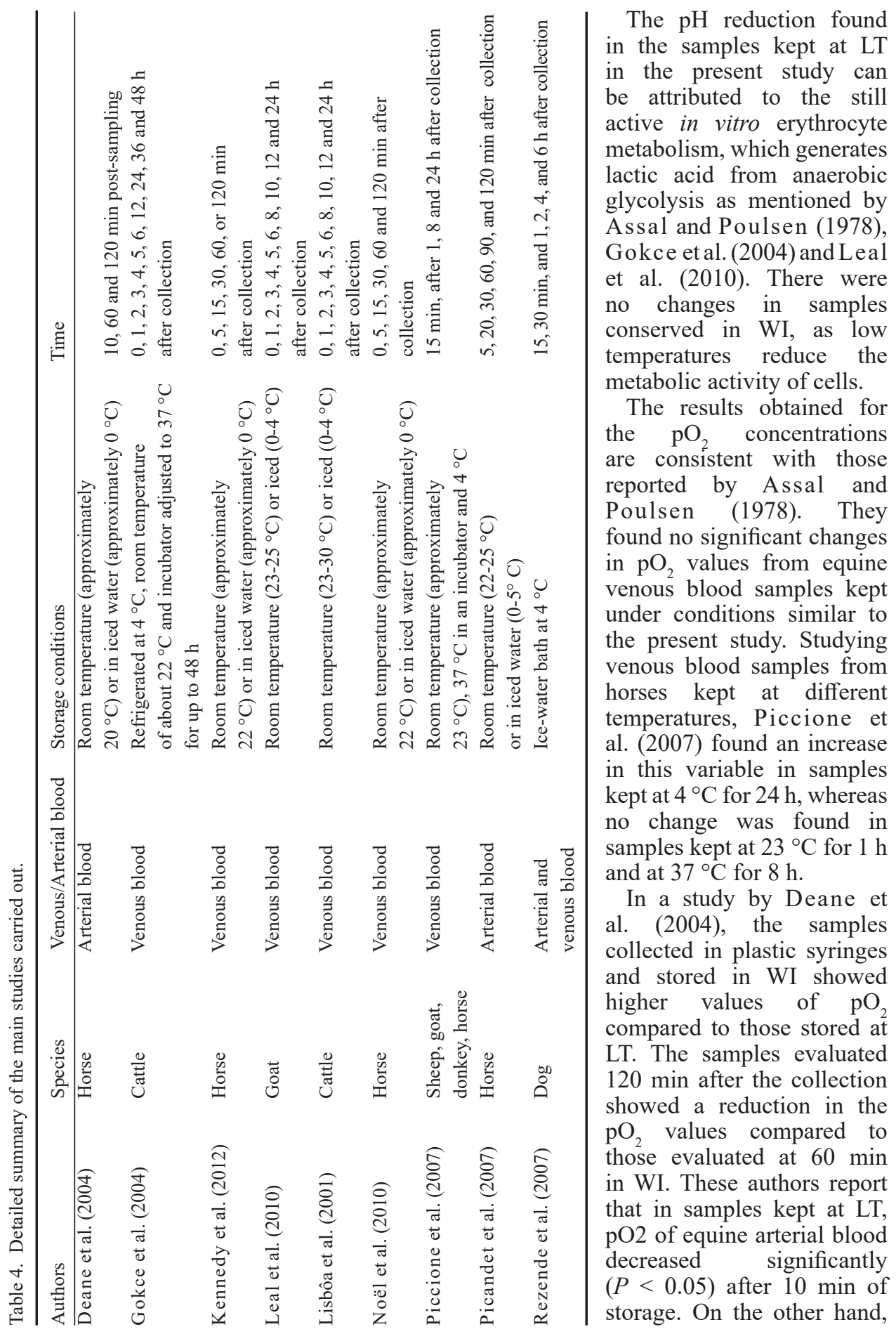


in a similar study, Picandet et al. (2007) reported an increase in horse arterial blood $\mathrm{pO}_{2}$ after 5 min of storage in WI and after 20 min of storage at LT. Small variations in temperature may be the reason for the differences found in these studies, since the temperatures of the laboratory and iced water vary, as can be seen in Table 4 . Another factor is the differences in syringes used, which can lead to significant changes in the values found. Plastic syringes used in the study by Deane et al. (2004) were heparinized using a pipette, whereas those used in the study by Picandet et al. (2007) already contained lithium heparin. Despite being commonly used in the laboratory routine due to its practicality, plastic vacutainer tubes can enable the diffusion of oxygen through the tube wall, which would lead to an increase in $\mathrm{O}_{2}$ in blood. According to Noël et al. (2010), heparinized vacutainer tubes should not be used to collect samples for measuring $\mathrm{pO}_{\text {. }}$.

In studies involving other domestic animal species, diverse results are reported. Lis bôa et al. (2001) recorded a significant reduction in the $\mathrm{pO}_{2}$ values in bovine venous blood samples at LT, and an increase in $\mathrm{pO}_{2}$ for those kept in WI. Gokce et al. (2004) observed also in venous blood from cattle an increase of this variable after $6 \mathrm{~h}$ of storage both at LT and in WI. In a similar study with goat venous blood, Leal et al. (2010) reported an increase in $\mathrm{pO}_{2}$ in samples kept in WI and in those kept at LT. Rezende et al. (2007) found an increase in $\mathrm{pO}_{2}$ in a study that evaluated changes caused by the storage of venous and arterial blood samples from dogs.

The fact that $\mathrm{pO}_{2}$ obtained in our study behaved differently than reported in the literature may be related to several factors that influence the $\mathrm{pO}_{2}$ concentration: permeability of the syringes used for storage (allows diffusion through the syringe), reduction in sample $\mathrm{pH}$ with changes of the affinity of haemoglobin for $\mathrm{O}_{2}$, and the aerobic consumption of $\mathrm{O}_{2}$ by nucleated cells and erythrocytes as described by Lisbôa et al. (2001), Deane et al. (2004), Gokce et al. (2004), Piccione et al. (2007), Rezende et al. (2007), Picandet et al. (2007) and Leal et al. (2010).

The values of $\mathrm{sO}_{2}$ and $\mathrm{ctCO}_{2}$ usually follow changes in $\mathrm{pO}_{2}$, since the events that determine changes in these variables are the same as those that influence $\mathrm{pO}_{2}$, however, this behaviour was not observed in the present study. Rezende et al. (2007) observed an increase in $\mathrm{sO}_{2}$ over time in venous and arterial blood samples from dogs kept in WI, whereas $\mathrm{ctCO}_{2}$ did not change. Studying changes in venous blood of cattle, Gokce et al. (2004) reported that $\mathrm{sO}_{2}$ increased after $24 \mathrm{~h}$ of storage at $4{ }^{\circ} \mathrm{C}$, and samples stored at LT did not change. Lisbôa et al. (2001) observed that $\mathrm{sO}_{2}$ and $\mathrm{ctCO}_{2}$ decreased after $3 \mathrm{~h}$ in bovine venous blood samples when kept at LT and remained stable when kept in WI for $24 \mathrm{~h}$. The results of Leal et al. (2010) for goat venous blood $\mathrm{sO}_{2}$ revealed a progressive decrease of the variable over the analysis period in the samples kept at LT. However, samples preserved with WI did not change until $10 \mathrm{~h}$ from the initial analysis. Noël et al. (2010) also found no changes in the values of $\mathrm{sO}_{2}$ and $\mathrm{ctCO}_{2}$.

Haemoglobin did not change between treatments. This result is in agreement with the results reported by Rezende et al. (2007), who found no changes in dog venous blood $\mathrm{cHb}$ stored in WI. In samples kept at LT, $\mathrm{pCO}_{2}$ values increased, whereas in samples kept in WI, the values remained unchanged. This result is consistent with the report by Assal and Poulsen (1978) who analyzed equine venous blood samples in the same manner as was used in this work. In the present study, variations in blood $\mathrm{pCO}_{2}$ kept at LT were probably due to the same factors mentioned by Assal and Poulsen (1978): the anaerobic erythrocyte metabolism still active during the storage period. As a result, there is an increase in the concentration of $\mathrm{H}^{+}$ions, which are buffered by $\mathrm{HCO}_{3}^{-}$producing $\mathrm{CO}_{2}$. The aerobic metabolism of leukocytes also generates $\mathrm{CO}_{2}$, but its contribution would be smaller in this situation. Kennedy et al. (2012) observed a significant increase in $\mathrm{pCO}_{2}$ concentrations in horse venous blood samples stored in different types of syringes and kept in WI at $0{ }^{\circ} \mathrm{C}$. The authors explain that part of the $\mathrm{CO}_{2}$ is likely to remain inside 
the wall of the plastic syringes since carbon dioxide is more soluble in propylene than oxygen.

Piccione et al. (2007) described a decrease in $\mathrm{pCO}_{2}$ in samples kept at LT during the first hour of storage, and in those kept at $4{ }^{\circ} \mathrm{C}$ where the decrease occurred after $24 \mathrm{~h}$. Analyzing horse arterial blood collected in plastic syringes and kept under conditions similar to the present study, Deane et al. (2004) and Picandet et al. (2007), observed no variations in $\mathrm{pCO}_{2}$ between the treatments or at different times within the treatments.

Studies similar to the present research involving other domestic animal species have brought diverse results. Lisbôa et al. (2001) analyzed venous blood from cattle. They described an increase of $\mathrm{pCO}_{2}$ starting at $3 \mathrm{~h}$ in samples kept at LT, whereas in samples kept in WI the increase occurred only after the $6^{\text {th }}$ hour of storage; after this time, there were successive increases. Analyzing cattle venous blood stored at $4{ }^{\circ} \mathrm{C}$, Gokce et al. (2004) recorded a decrease in the $\mathrm{pCO}_{2}$ values after $1 \mathrm{~h}$ of collection. Samples kept at 22 and $37{ }^{\circ} \mathrm{C} \mathrm{pCO}_{2}$ increased starting $4 \mathrm{~h}$ of collection. Rezende et al. (2007) analyzed changes in the arterial blood of dogs kept in WI using 1 or $3 \mathrm{ml}$ syringes, reporting that in the $1 \mathrm{ml}$ samples, $\mathrm{pCO}_{2}$ remained stable throughout the experimental period, while there was an increase in the $3 \mathrm{ml}$ samples starting from $6 \mathrm{~h}$ of storage. The increase in $\mathrm{pCO}_{2}$ was also reported by Leal et al. (2010) when studying goat venous blood from the $1^{\text {st }} \mathrm{h}$ of storage at LT and from the $6^{\text {th }} \mathrm{h}$ in samples kept in WI.

The results for $\mathrm{CHCO}_{3}{ }^{-}$are similar to those described by Piccione et al. (2007) in a similar study with horse venous blood. In studies involving venous blood from goats and dogs, no differences were found in samples kept in WI or kept at LT over time (Rezende et al. 2007; Leal et al. 2010). In studies involving cattle venous blood, diverse results were found. Lisbôa et al. (2001) did not observe changes in samples kept at LT and WI, whereas Gokce et al. (2004) reported an increase in bicarbonate concentrations in samples kept at 4,22 and $37^{\circ} \mathrm{C}$.

A decrease in cBase was observed in samples kept at LT also by Assal and Poulsen (1978) in horse venous blood. Piccione et al. (2007) also reported a reduction in cBase in equine venous blood samples kept at 22, 37 and $4{ }^{\circ} \mathrm{C}$. In bovine venous blood preserved in a similar way to the present study, Lisbôa et al. (2001) and Gokce et al. (2004) also describe a reduction of the variable over time. This result is compatible with the $\mathrm{pH}$ values of this study, because with the decrease in $\mathrm{pH}$, cBase decreased as well, showing the activity of buffering mechanisms during the analysis. The variation was smaller in the samples conserved in WI since the low temperature reduced cellular metabolism and consequently, blood acidification.

There was no change in concentrations of $\mathrm{Na}^{+}, \mathrm{Ca}^{++}$and $\mathrm{Cl}^{-}$. In the case of these electrolytes, it is possible to allude to what was described by Costa Jr (2006) for dog whole blood stored in a plastic blood bag at $4{ }^{\circ} \mathrm{C}$ : he stated that the $\mathrm{Na}^{+}, \mathrm{Ca}^{++}$and $\mathrm{Cl}^{-}$electrolytes were mainly present in the extracellular fluid, and their concentrations did not change when there was no loss or gain of water into the storage container, whereas potassium was present mainly in the intracellular fluid (ICF). In the body, only $2 \%$ of organic potassium is present in the extracellular fluid (ECF). This balance is mainly maintained by the "sodium-potassium pump" of the plasma membrane. At low temperatures, the function of the sodium-potassium pump is considerably reduced, leading to a decrease in cytosolic potassium levels while increasing the sodium influx (Costa Jr 2006).

Storing samples at temperatures close to zero can delay the expected acid-base changes, possibly due to inhibition of erythrocyte metabolism (Lisbôa et al. 2001). The scarcity of this type of study in the equine species demonstrates the need for further studies addressing the subject; also, the methodology used is efficient and easy to perform.

It is concluded that conservation of equine venous blood samples in WI is efficient in reducing cellular metabolism, increasing the viability of the samples for the examination 
and interpretation of results. According to the results of this study, horse venous blood can be used for blood gas analysis for up to $12 \mathrm{~h}$ after collection, provided it is stored in a container with WI. At LT, it remains viable for $2 \mathrm{~h}$ after collection.

\section{References}

Assal AN, Poulsen JSD 1978: Acid base status of equine blood during storage. Nord Vet Med 30: 354-363

Bateman SW 2008: Making sense of blood gas results. Vet Clin North Am Small Anim Pract 38: 543-557

Costa Junior JD 2006: Avaliação do sangue total de cães armazenado em bolsas plásticas contendo CPDA-1 e CDP/SAG-M. Dissertation (Masters), Universidade Federal de Viçosa, Viçosa. 38 p.

Deane JC, Dagleish MP, Benamou AE, Wolf BT, Marlin D 2004: Effects of syringe material and temperature and duration of storage on the stability of equine arterial blood gas variables. Vet Anaesth Analg 31: 250-257

Gokce G, Citil M, Gunes V, Atalan G 2004: Effect of time delay and storage temperature on blood gas and acid base values of bovine venous blood. Res Vet Sci 76: 121-127

Kennedy SA, Constable PD, Sen I, Couëtil L 2012: Effects of syringe type and storage conditions on results of equine blood gas and acid-base analysis. AJVR 73: 979-987

Klein LV, Soma LR, Nann LE 1999: Accuracy and precision of the portable StatPal II and the laboratory-based NOVA Stat Profile 1 for measurement of $\mathrm{pH}, \mathrm{PCO}_{2}$, and $\mathrm{PO}_{2}$ in equine blood. Vet Surg 28: 67-76

Leal MLR, Soares PC, Cyrillo FC, Benesi FJ 2010: Influence of refrigeration on blood gas analysis of caprine venous blood. Braz J Vet Res Anim Sci 47: 105-110

Lisbôa JAN, Benesi FJ, Maruta CA, Mirandola RMS, Teixeira CMC 2001: Tempo de viabilidade de amostras de sangue venoso bovino destinadas ao exame hemogasométrico, quando mantidas sob conservação em água gelada. Cien Rural 31: 271-276

Looney AL, Ludders J, Erb HN, Gleed R, Moon P 1998: Use of a handheld device for analysis of blood electrolyte concentrations and blood gas partial pressures in dogs and horses. J Am Vet Med Assoc 213: 526-530

Noël PG, Couëtil L, Constable PD 2010: Effects of collecting blood into plastic heparinised Vacutainer ${ }^{\mathbb{E}}$ tubes and storage conditions on blood gas analysis values in horses. Equine Vet J 42: 91-97

Picandet V, Jeanneret S, Lavoie JP 2007: Effects of syringe type and storage temperature on results of blood gas analysis in arterial blood of horses. J Vet Intern Med 21: 476-481

Piccione G, Bertolucci C, Grasso F, Giudice E 2007: Changes in gas composition and acid base values of venous blood samples stored under different conditions in 4 domestic species. Vet Clin Pathol 36: 358-360

Rezende ML, Haskins SC, Hopper K 2007: The effects of ice-water storage on blood gás and acid-base measurements. J Vet Emerg Crit Care 17: 67-71

Ribeiro Filho JD, Abreu JMG, Alves GES, Dantas WMF 2007: Hemogasometria em equinos com compactação experimental do cólon maior tratados com sene, fluidoterapia enteral e parenteral. Cien Rural 37: 755-761

Ribeiro Filho JD, Balbinot PZ, Viana JA, Dantas WMF, Monteiro BS 2008: Hemogasometria em cães com desidratação experimental tratados com soluções eletrolíticas comerciais administradas por via intravenosa. Cien Rural 38: 1914-1919

Robinson NE 2004: Homeostase ácido básica. In: Cunningham JG ( $2^{\text {nd }}$ edn): Tratado de fisiologia veterinária. Guanabara Koogan, Rio de Janeiro, pp. 539-550

SAEG 2007: Sistema para análises estatísticas. Versão 9.1. Viçosa: UFV. Fundação Arthur Bernardes, 301 p. 